\title{
Erratum to: IL28B SNP screening and distribution in the French Canadian population using a rapid PCR-based test
}

\author{
Jean-François Gélinas • Thomas Fabre • Philippe Willems • \\ Reynold C. Leung • Jacob George • Bernard Willems • \\ Julie Bruneau • Naglaa H. Shoukry
}

Published online: 1 March 2015

(C) Springer-Verlag Berlin Heidelberg 2015

Erratum to: Immunogenetics (2013) 65:397-403

DOI 10.1007/s00251-013-0688-7

We have realized very recently that two of the primer sets and PCR conditions described in the paper unintentionally listed the sequences of two earlier sets of primers that were suboptimal.
The final primer sets and PCR conditions used to generate all the data in the paper are now listed in a revised version of Table 1 (below). This revised set of primers and conditions were reordered and re-tested as an additional confirmation step.

Table 1 IL28B PCR and sequencing primers

\begin{tabular}{|c|c|c|}
\hline Primer name & Sequence (5'-3') & Description \\
\hline \multicolumn{3}{|l|}{ rs12979860 } \\
\hline rs12-Reverse & CCCAGCAGGCGCCTCTCCTA & reverse primer for all purposes \\
\hline rs12-Forward-Seq & GAGGATCCCTCCTGGGGCG & forward primer for sequencing \\
\hline rs12-Forward-C & GGAGCTCCCCGAAGGCGC & forward primer for testing genotype $\mathrm{C}$ \\
\hline rs12-Forward-T & GGGAGCTCCCCGAAGGCGT & forward primer for testing genotype $T$ \\
\hline \multicolumn{3}{|l|}{ rs8099917 } \\
\hline rs80-Forward & CCACTTCTGGAACAAATCGTC & forward primer for all purposes \\
\hline rs80-Reverse-Seq & TTAGGCCTGTGGATGAGGC & reverse primer for sequencing \\
\hline rs 80 -Reverse-G & GGTTCCAATTTGGGTGAC & reverse primer for testing genotype $G$ \\
\hline rs80-Reverse- $\mathrm{T}$ & GGTTCCAATTTGGGTGAA & reverse primer for testing genotype $T$ \\
\hline
\end{tabular}

The online version of the original article can be found at http://dx.doi.org/ 10.1007/s00251-013-0688-7.

J.-F. Gélinas · T. Fabre • P. Willems • B. Willems · J. Bruneau •

N. H. Shoukry $(\bowtie)$

Hôpital St-Luc, Centre de Recherche du Centre Hospitalier de

l'Université de Montréal (CRCHUM), 264 boul. René-Lévesque Est, Local PEA-316, Montréal, Québec H2X 1P1, Canada

e-mail: naglaa.shoukry@umontreal.ca

T. Fabre

Département de microbiologie et immunologie,

Université de Montréal, Montréal, Quebec, Canada

R. C. Leung $\cdot$ J. George

Storr Liver Unit, Westmead Millennium Institute, Westmead

Hospital, University of Sydney, Sydney, New South Wales, Australia
B. Willems $\cdot$ N. H. Shoukry

Département de médecine, Université de Montréal,

Montréal, Québec, Canada

J. Bruneau

Département de médicine familiale, Université de Montréal, Montréal, Québec, Canada

Present Address:

J.-F. Gélinas

Gene Medicine Research Group, John Radcliffe Hospital,

University of Oxford, Oxford, UK 


\section{Correction for PCR conditions within Patients and Methods section (Changes are underlined):}

PCR amplification and IL28B genotyping by sequencing: PCR conditions were as follows: initial denaturation cycle at $94^{\circ} \mathrm{C}$ for $2 \mathrm{~min}, 35$ amplification cycles (for rs12979860) or 40 amplification cycles (for rs 8099917 ) of $94^{\circ} \mathrm{C}$ for $30 \mathrm{~s}$, $55.5^{\circ} \mathrm{C}$ for $1 \mathrm{~min}$, and $72{ }^{\circ} \mathrm{C}$ for $3 \mathrm{~min}$. rs 12979860 .

\section{IL28B screening by PCR:}

PCR conditions in thermocycler (Biometra, Goettingen, Germany) were as follows: initial denaturation at $94^{\circ} \mathrm{C}$ for 2 min, followed by 35 cycles of $94^{\circ} \mathrm{C}$ for $30 \mathrm{~s}, 65^{\circ} \mathrm{C}$ for $15 \mathrm{~s}$, and $72^{\circ} \mathrm{C}$ for $1 \mathrm{~min}$ for $\mathrm{rs} 12979860$ or 40 cycles of $94^{\circ} \mathrm{C}$ for $30 \mathrm{~s}, 54.5^{\circ} \mathrm{C}$ for $15 \mathrm{~s}$, and $72^{\circ} \mathrm{C}$ for $1 \mathrm{~min}$ for rs 8099917 .

\section{Additional Corrections to the Text:}

Page 399, paragraph entitled: "Development of a rapid PCRbased screening for IL28B SNPs",

Line 6: The sentence, without the word "reverse", should read: "The test primers were designed so that the last nucleotide is the targeted SNP and the primer would therefore anneal or not depending on the patient's or sample genotype".

We sincerely regret the unintentional error. 